\title{
Role of the SIRT1/p53 regulatory axis in oxidative stress-mediated granulosa cell apoptosis
}

\author{
SANG-AH PARK ${ }^{*}$, NA-RAE JOO*, JUNG-HWAN PARK and SANG-MUK OH \\ Department of Biochemistry, Priority Research Center, Myunggok Medical Research Institute, \\ College of Medicine, Konyang University, Daejeon 35365, Republic of Korea
}

Received April 6, 2020; Accepted September 11, 2020

DOI: $10.3892 / \mathrm{mmr} .2020 .11658$

\begin{abstract}
Oxidative stress has been suggested to induce granulosa cell apoptosis, which contributes to follicular atresia. However, the mechanism via which oxidative stress mediates granulosa cell apoptosis remains elusive. Therefore, the aim of this study was to elucidate the molecular mechanisms regulating oxidative stress-induced granulosa cell apoptosis. The present study demonstrated that reactive oxygen species induced by $\mathrm{H}_{2} \mathrm{O}_{2}$ resulted in human granulosa COV434 cell apoptosis via the regulation of sirtuin 1 (SIRT1)-mediated p53 activity. Endogenous SIRT1 expression was alleviated by $\mathrm{H}_{2} \mathrm{O}_{2}$ treatment of COV434 cells in a time-dependent manner. In addition, knockdown or inhibition of SIRT1 promoted $\mathrm{H}_{2} \mathrm{O}_{2}$-induced poly(ADP-ribose) polymerase (PARP) cleavage and p53 acetylation, which led to an increase in COV434 cell apoptosis. Treatment with $\mathrm{H}_{2} \mathrm{O}_{2}$ enhanced the expression levels of the p53-dependent proteins, p53-upregulated modulator of apoptosis (PUMA) and phorbol-12-myristate-13-acetate-induced protein 1 (PMAIP1), as well as those of p53; however, knockdown of p53 decreased cleaved PARP, PUMA and PMAIP1 expression levels induced by $\mathrm{H}_{2} \mathrm{O}_{2}$ treatment. Moreover, knockdown of PUMA or PMAIP1 attenuated the $\mathrm{H}_{2} \mathrm{O}_{2}$ induction of PARP cleavage and COV434 cell apoptosis. In conclusion, the present findings suggested that $\mathrm{H}_{2} \mathrm{O}_{2}$-induced oxidative stress causes granulosa COV434 cell apoptosis via the upregulation of p53 activity by SIRT1 suppression, indicating a mechanistic role of the SIRT1/p53 axis in $\mathrm{H}_{2} \mathrm{O}_{2}$-induced granulosa cell apoptosis.
\end{abstract}

Correspondence to: Professor Sang-Muk Oh, Department of Biochemistry, Priority Research Center, Myunggok Medical Research Institute, College of Medicine, Konyang University, Daejeon 35365, Republic of Korea

E-mail: sangmuk_oh@konyang.ac.kr

*Contributed equally

Key words: granulosa cell, oxidative stress, sirtuin 1, p53, apoptosis

\section{Introduction}

Most follicles undergo degeneration during ovarian follicular development in a process called follicular atresia (1). It has been reported that women ovulate $\sim 400$ primary oocytes from the 2 million cells present at birth (2). Commonly, 20 follicles mature each month, but only one follicle is ovulated, and the remaining cells undergo follicular atresia (1). Furthermore, diseases such as premature ovarian insufficiency (POI) are observed with increased follicular atresia (3). Granulosa cell apoptosis has been revealed to cause follicular atresia $(4,5)$. It has been demonstrated that granulosa cells are essential in determining follicular growth or atresia, and are considered initial cell populations that undergo apoptosis in atretic follicles earlier than oocytes and theca cells, indicating their role as the trigger of follicular atresia (1). It has been proposed that granulosa cells are in continuous communication with the oocyte (6). Additionally, granulosa cells provide the oocyte with biological products, including sugars, amino acids and nucleotides, that sustain its metabolic activity, as well as signals that regulate its differentiation or maturation (7). Therefore, the regulation of granulosa cell apoptosis is important for the maintenance of ovarian health. It has also been reported that oxidative stress induced by 3-nitropropionic acid decreases the number of large follicles, increases follicular atresia in mouse ovaries and downregulates SIRT1 expression, leading to FoxO1 activation and granulosa cell apoptosis $(8,9)$. Furthermore, knockout of mouse double minute 2 (Mdm2), a major p53-negative regulator, results in a decline in the number of growing follicles in the ovaries $(10,11)$. These findings suggest that Mdm2 regulating p53 serves a critical role in ovary health, ultimately affecting follicular atresia or POI.

Sirtuin1 (SIRT1) is a NAD(+)-dependent histone deacetylase protein and is involved in various cellular processes, including proliferation, inflammation, aging and apoptosis, via its deacetylase activity (12-17). It has been suggested that SIRT1 acts as an anti-apoptotic effector in granulosa cell apoptosis (18). p53 is a known tumor suppressor protein and is a transcription factor regulated by SIRT1 (19). The activity of p53 as a transcription factor controls the expression of target genes, such as p21, PUMA and Bax, and induces cell cycle arrest, senescence and cell death $(20,21)$. Activated p53 can also induce apoptosis via the $\mathrm{Bcl}-2$-regulated pathway initiated by upregulation of $\mathrm{BH} 3$-only 
members of the Bcl-2 protein family, including BCL2 like 11 (BIM), p53-upregulated modulator of apoptosis (PUMA) and phorbol-12-myristate-13-acetate-induced protein 1 (PMAIP1), which are direct transcriptional targets of p53 (22). PUMA or PMAIP1 directly bind to Bax or Bcl2 antagonist/killer 1 to increase their proapoptotic activity. Additionally, p53 has been implicated in granulosa cell apoptosis (23). However, to the best of our knowledge, there is no mechanistic information linking SIRT1 with p53 activity in granulosa cell apoptosis.

The present study aimed to elucidate the regulatory mechanism of granulosa cell apoptosis. Hydrogen peroxide was used to generate reactive oxygen species. Flow cytometry and TUNEL assays were employed to measure cell apoptosis, while small interfering (si)RNA and short hairpin (sh)RNA against PUMA, PMAIP1 or p53 were used to suppress target gene expression. Furthermore, immunoblotting and reverse transcription-quantitative (RT-qPCR) were performed to examine the expression of PARP, caspase-3, p53, PUMA and PMAIP1.

\section{Materials and methods}

Cell lines and reagents. Human granulosa COV434 cells were purchased from Sigma-Aldrich (Merck KGaA), and were maintained in high glucose DMEM (Thermo Fisher Scientific, Inc.) supplemented with $10 \%$ FBS (Atlas Biologicals, Inc.), 2 mM L-glutamine (Sigma-Aldrich; Merck KGaA), $1 \%$ penicillin/streptomycin (Thermo Fisher Scientific, Inc.) at $37^{\circ} \mathrm{C}$ in a $\mathrm{CO}_{2}$ incubator. $293 \mathrm{~T}$ cells were purchased from the American Type Culture Collection, and were maintained in high glucose DMEM supplemented with $10 \%$ FBS, $1 \%$ penicillin/streptomycin at $37^{\circ} \mathrm{C}$ in a $\mathrm{CO}_{2}$ incubator.

Rabbit anti-SIRT1 (cat. no. ab32441), mouse anti-p53 (cat. no. ab26) and mouse anti-PMAIP1 (cat. no. ab13654) antibodies $(1: 2,000)$ were purchased from Abcam. Rabbit anti-cleaved caspase-3 (cat. no. sc7148; 1:500) antibody was purchased from Santa Cruz Biotechnology, Inc. Rabbit anti-cleaved poly(ADP-ribose) polymerase (PARP; cat. no. 9541), rabbit anti-PUMA (cat. no. 4976) and rabbit anti-acetyl p53 (Lys382; cat. no. 2525) antibodies $(1: 2,000)$ were purchased from Cell Signaling Technology, Inc. HRP-conjugated goat anti-rabbit IgG polyclonal (cat.no. ADI-SAB-300-J) and HRP-conjugated goat anti-mouse IgG F(ab')2, polyclonal (cat. no. ADI-SAB-100-J) antibodies $(1: 2,000)$ were purchased from Enzo Life Sciences, Inc. Z-VAD-FMK was purchased from Selleck Chemicals. Mouse anti- $\beta$-actin antibody (cat. no. A5441; $1: 4,000$ ), hexadimethrine bromide, $\mathrm{H}_{2} \mathrm{O}_{2}$, EX527 and $\mathrm{N}$-acetyl-L-cysteine (NAC) were purchased from Sigma-Aldrich (Merck KGaA). SRT1720 was purchased from MedChemExpress. 2',7'-Dichlorofluorescein diacetate (H2DCFDA), Annexin V-FITC antibody and PI were purchased from Thermo Fisher Scientific, Inc. The TUNEL assay kit was purchased from Promega Corporation. The Transcriptor First Strand cDNA Synthesis kit and FastStart Essential DNA Green Master were purchased from Roche Diagnostics.

Plasmid and production of lentiviral vectors. ON-TARGET plus non-targeting control pool (cat. no. D-001810-10-05), ON-TARGET plus Human TP53 siRNA-SMART pool (cat. no. L-003329-00-0005), ON-TARGET plus Human PUMA siRNA-SMART pool (cat. no. L-004380-00-0005) and ON-TARGET plus Human PMAIP1 siRNA-SMART pool (cat. no. L-005275-00-0005) were purchased from GE Healthcare Dharmacon, Inc. pMDLg/pRRe (Addgene plasmid no. 12251), pRSV-Rev (Addgene plasmid no. 12253) and pMD2.G (Addgene plasmid no. 12259) were gifted by Didier Trono. pLKO.1-luc and SIRT1 MISSION short hairpin (sh)RNA were purchased from Sigma-Aldrich (Merck KGaA).

A total of $1 \times 10^{6} 293 \mathrm{~T}$ cells were seeded in $100-\mathrm{mm}$ cell culture dishes. According to Trono Lab protocols, packaging plasmids $2 \mu \mathrm{g} \mathrm{pMDLg/pRRe} \mathrm{and} 1 \mu \mathrm{g}$ pRSV-Rev plus envelope plasmid $1.2 \mu \mathrm{g}$ pMD2.G were transfected with each $4 \mu \mathrm{g}$ SIRT1 knockdown vector or $4 \mu \mathrm{g}$ pLKO.1-luc control vector into $293 \mathrm{~T}$ cells using Effectene transfection reagents (Qiagen $\mathrm{GmbH}$ ). Following $48 \mathrm{~h}$ of transfection, media containing shRNA-generated lentivirus were collected, purified via $0.45-\mu \mathrm{m}$ syringe filters, concentrated using a Lenti- $\mathrm{X}^{\mathrm{TM}}$ concentrator (Takara Bio, Inc.) and then titered using a Lenti- $\mathrm{X}^{\mathrm{TM}}$ p24 Rapid titer kit (Takara Bio, Inc.). The absorbance was determined at $450 \mathrm{~nm}$ using SPECTROstar ${ }^{\circledR}$ Nano.

Gene silencing using siRNA and shRNA. COV434 cells $\left(1 \times 10^{6}\right)$ growing on $60-\mathrm{mm}$ cell culture dishes were incubated with fresh media with a final concentration of hexadimethrine bromide at $8 \mathrm{mg} / \mathrm{ml}$ to enhance transduction of most cell types. Lentivirus-mediated SIRT1 shRNA transduction was performed at a multiplicity of infection of 10. Following $48 \mathrm{~h}$ of transduction, cells were collected and lysed.

For siRNA knockdown, COV434 cells $\left(1 \times 10^{6}\right)$ growing on $60-\mathrm{mm}$ cell culture dishes were transfected with $40 \mathrm{nM}$ non-targeting siRNA or $40 \mathrm{nM}$ p53 siRNA using Lipofectamine $^{\circledR} 3000$ (Invitrogen; Thermo Fisher Scientific, Inc.). Following $48 \mathrm{~h}$ of transfection, cells were collected and lysed.

Flow cytometry analysis. COV434 cells growing on 60-mm dishes were pretreated with the SIRT1 inhibitor $20 \mu \mathrm{M}$ EX527 or the SIRT1 activator $1 \mu \mathrm{M}$ SRT1720 for $2 \mathrm{~h}$, and then treated with $0.5 \mathrm{mM} \mathrm{H}_{2} \mathrm{O}_{2}$ for $6 \mathrm{~h}$ at $37^{\circ} \mathrm{C}$. The time gradient was determined based on recent study (24). Additionally, COV434 cells were transfected with non-targeting siRNA or p53 siRNA for $48 \mathrm{~h}$, and then incubated with $\mathrm{H}_{2} \mathrm{O}_{2}$ for $6 \mathrm{~h}$ at $37^{\circ} \mathrm{C}$. Apoptosis analysis was performed using Annexin V-FITC and PI according to the manufacturer's instructions (Thermo Fisher Scientific, Inc.). Data were acquired using FACSCalibur (BD Biosciences) and were analyzed using BD Cell Quest ${ }^{\mathrm{TM}}$ Pro version 6.5.1 (BD Biosciences). The apoptotic rate was calculated using the percentage of early and late apoptotic cells.

Cellular reactive oxygen species detection assay. COV434 cells growing on confocal dishes at $80 \%$ confluency were pretreated with $5 \mathrm{mM} \mathrm{NAC}$ for $2 \mathrm{~h}$ and incubated at $37^{\circ} \mathrm{C}$ with $\mathrm{H}_{2} \mathrm{O}_{2}$ for 2,4 or $6 \mathrm{~h}$. The conditioned media were removed, and fresh media containing $10 \mathrm{mM}$ DCF-DA were added. The cells were incubated at $37^{\circ} \mathrm{C}$ for $20 \mathrm{~min}$. After incubation, the conditioned media were removed and washed with prewarmed PBS. The media were replaced with prewarmed PBS containing $1 \% \mathrm{FBS}$, and the cells were incubated at $37^{\circ} \mathrm{C}$ 
for $10 \mathrm{~min}$. Data analysis was performed using a Zeiss LSM 710 laser-scanning confocal microscope (magnification, x20; Zeiss $\mathrm{GmbH}$ ).

TUNEL assay. COV434 cells $\left(1 \times 10^{6}\right)$ were seeded on cover glasses in 6-well plates. After $24 \mathrm{~h}$, cells were pretreated with $20 \mu \mathrm{M}$ EX527 or $1 \mu \mathrm{M}$ SRT1720 for $2 \mathrm{~h}$, and then incubated at $37^{\circ} \mathrm{C}$ with $\mathrm{H}_{2} \mathrm{O}_{2}$ for $6 \mathrm{~h}$. Additionally, COV434 cells were transfected with $40 \mathrm{nM}$ non-targeting siRNA or $40 \mathrm{nM}$ PMAIP1 siRNA for $48 \mathrm{~h}$, and then treated with $0.5 \mathrm{mM} \mathrm{H}_{2} \mathrm{O}_{2}$ for $6 \mathrm{~h}$ at $37^{\circ} \mathrm{C}$. Cells were washed with ice-cold Dulbecco's PBS (DPBS; Welgene, Inc.) and fixed with $4 \%$ formaldehyde in DPBS at $4^{\circ} \mathrm{C}$ for $25 \mathrm{~min}$. Cells were washed with DPBS for $5 \mathrm{~min}$ at room temperature twice and permeabilized with $0.2 \%$ Triton X-100 solution in DPBS for 5 min. After rinsing the cover glasses using DPBS, equilibration buffer was added to pre-equilibrate for $10 \mathrm{~min}$ at room temperature. The fragmented DNA of apoptotic cells was stained with equilibration buffer, nucleotide mix and terminal deoxynucleotidyl transferase (rTdT) for $1 \mathrm{~h}$ at $37^{\circ} \mathrm{C}$. $2 \mathrm{X} \mathrm{SSC}$ was added to stop the reaction for $15 \mathrm{~min}$ at room temperature. After washing twice, cells were stained with 1:10,000 DAPI in DPBS for $15 \mathrm{~min}$ at room temperature. After washing twice, cover glasses were mounted using mounting medium (Thermo Fisher Scientific, Inc.). Equilibration buffer, nucleotide mix, rTdT and SSC were contained in the TUNEL assay kit (Promega Corporation) and their concentration was determined according to manufacturer's instructions. Five sections of the cover glass were imaged at x20 magnification. Data analysis was performed using a laser-scanning confocal microscope Zeiss LSM 710 (Zeiss $\mathrm{GmbH})$.

Immunoblot analysis. COV434 cells $\left(1 \times 10^{6}\right)$ grown on $60 \mathrm{~mm}$ dishes were pretreated with $5 \mathrm{mM}$ NAC, $50 \mu \mathrm{M}$ Z-VAD-FMK, $20 \mu \mathrm{M}$ Ex527 or DMSO at $37^{\circ} \mathrm{C}$ for $2 \mathrm{~h}$, and then treated with $0.5 \mathrm{mM} \mathrm{H}_{2} \mathrm{O}_{2}$ for $6 \mathrm{~h}$ at $37^{\circ} \mathrm{C}$. For immunoblotting, COV434 cells were harvested and lysed using lysis buffer containing $0.5 \%$ Triton X-100, $1 \mathrm{mM}$ EDTA, $50 \mathrm{mM}$ Tris- $\mathrm{HCl}, \mathrm{pH} 7.4$ and $40 \mathrm{mM} \mathrm{NaCl}$. Cell lysates were diluted at 1:1,000 in protein assay dye reagent (Bio-Rad Laboratories, Inc.) and densitometry was measured at $595 \mathrm{~nm}$ by SPECTROstar ${ }^{\circledR}$ Nano. Briefly, $30 \mu \mathrm{g}$ cell lysate was separated via 10,12 or $16 \%$ SDS-PAGE and transferred to nitrocellulose membranes (Bio-Rad Laboratories, Inc.). The membranes were blocked with 5\% skim milk in TBS with $1 \%$ Tween 20 (TBST) for $1 \mathrm{~h}$ at room temperature, and then incubated with anti-p53, acetyl p53, cleaved PARP, cleaved caspase-3, SIRT1, PUMA, PMAIP1 or $\beta$-actin antibodies at $4^{\circ} \mathrm{C}$ overnight. The membranes were washed three times using TBST and then incubated with secondary antibodies, including goat anti-rabbit polyclonal antibody and goat anti-mouse polyclonal antibody at room temperature for $1 \mathrm{~h}$. After washing, the blot was detected with a western detection kit (AbClon, Inc.), according to the manufacturer's instructions, and X-ray film. Protein expression was analyzed using ImageJ 1.52t (National Institutes of Health).

$R T$-qPCR. To quantify $p 53, B A X, B I M, P M A I P 1, P U M A$ and $G A P D H$ mRNA expression, cells were lysed with TRIzol ${ }^{\circledR}$ reagent (Ambion, Inc.). Total RNA $(2 \mu \mathrm{g})$ was synthesized into
cDNA using the Transcriptor First Strand cDNA Synthesis kit (Roche Diagnostics) according to the manufacturer's instructions. qPCR was performed using FastStart Essential DNA Green Master mix (Roche Diagnostics). Data were obtained using a LightCycler ${ }^{\circledR} 96$ Instrument (Roche Diagnostics) and consisted of three programs: Preincubation, 3-step amplification and melting. The 'preincubation' program was set to a temperature of $95^{\circ}$, ramp of $4.4^{\circ} \mathrm{C} / \mathrm{sec}$, duration of $600 \mathrm{sec}$ and no acquisition mode. The ' 3 -step amplification' program was set to a temperature of $95^{\circ} \mathrm{C}$ for $10 \mathrm{sec}, 60^{\circ} \mathrm{C}$ for $10 \mathrm{sec}$ and $72^{\circ} \mathrm{C}$ for $10 \mathrm{sec}$, and the number of cycles was 40 . The 'melting' program was set to $95^{\circ} \mathrm{C}$ for $10 \mathrm{sec}, 65^{\circ} \mathrm{C}$ for $60 \mathrm{sec}$ and $97^{\circ} \mathrm{C}$ for $1 \mathrm{sec}$. Data analysis was performed using LightCycler $^{\circledR} 96$ SW 1.1 (Roche Diagnostics). Relative gene expression data was analyzed with the $2^{-\Delta \Delta \mathrm{Cq}}$ method (25). All primers were purchased from Bioneer Corporation, and their sequences were as follows: p53 forward, 5'-AGGCCT TGGAACTCAAGGAT-3' and reverse, 5'-CCCTTTTTGGAC TTCAGGTG-3'; BAX forward, 5'-TTGCTTCAGGGTTTC ATCCA-3' and reverse, 5'-AGACACTCGCTCAGCTTCTTG -3'; BIM forward, 5'-CAAGTTCAAGCGGTTCTCCT-3' and reverse, 5'-CAGCCTGCCTCATGGAAG-3'; PUMA forward, 5'-GACGACCTCAACGCACAGTA-3' and reverse, 5'-AGG AGTCCCATGATGAGATTGT-3'; PMAIP1 forward, 5'-GGA GATGCCTGGGAAGAAG-3' and reverse, 5'-CCTGAGTTG AGTAGCACACTCG-3; and GAPDH forward, 5'-AGCCAC ATCGCTCAGACAC-3' and reverse, 5'-GCCCAATACGAC CAAATCC-3'.

Statistical analysis. Data are presented as the mean \pm SD of $\geq 3$ independent experiments in duplicate. Statistical analysis was performed using one-way ANOVA with Tukey's test or two-way ANOVA followed by Bonferroni's correction. $\mathrm{P}<0.05$ were considered to indicate a statistically significant difference.

\section{Results}

$\mathrm{H}_{2} \mathrm{O}_{2}$-induced $\mathrm{ROS}$ production results in COV434 granulosa cell apoptosis and decreases SIRT1 expression. The effect of $\mathrm{H}_{2} \mathrm{O}_{2}$ on COV434 granulosa cell apoptosis was examined, and it was identified that $\mathrm{H}_{2} \mathrm{O}_{2}$ treatment induced granulosa cell apoptosis dose-dependently (Fig. 1A). Next, it was investigated whether endogenous ROS were generated by $\mathrm{H}_{2} \mathrm{O}_{2}$ treatment in granulosa cells. COV434 cells were treated with or without $\mathrm{H}_{2} \mathrm{O}_{2}$ for 2,4 or $6 \mathrm{~h}$. The results indicated that endogenous ROS levels were slightly increased following $2 \mathrm{~h}$ of $\mathrm{H}_{2} \mathrm{O}_{2}$ treatment, but elevated $\sim 1.5$ - or 2 -fold after 4 or $6 \mathrm{~h}$ of $\mathrm{H}_{2} \mathrm{O}_{2}$ treatment, respectively (Fig. 1B).

Subsequently, the effect of oxidative stress on COV434 cell apoptosis was evaluated. COV434 cells were incubated with or without $\mathrm{H}_{2} \mathrm{O}_{2}$ for 2,4 or $6 \mathrm{~h}$, and apoptotic cells were increased $\sim 2$-fold after $6 \mathrm{~h}$ of $\mathrm{H}_{2} \mathrm{O}_{2}$ treatment (Fig. 1C). Furthermore, the expression levels of cleaved PARP or caspase-3 were significantly increased by $\mathrm{H}_{2} \mathrm{O}_{2}$ treatment in a time-dependent manner (Fig. 1D). It has been suggested that SIRT1 provides resistance to apoptosis induced by oxidative stress (26). As expected, SIRT1 expression was decreased by $\mathrm{H}_{2} \mathrm{O}_{2}$ treatment (Fig. 1D), which may affect $\mathrm{H}_{2} \mathrm{O}_{2}$-induced granulosa cell apoptosis. 

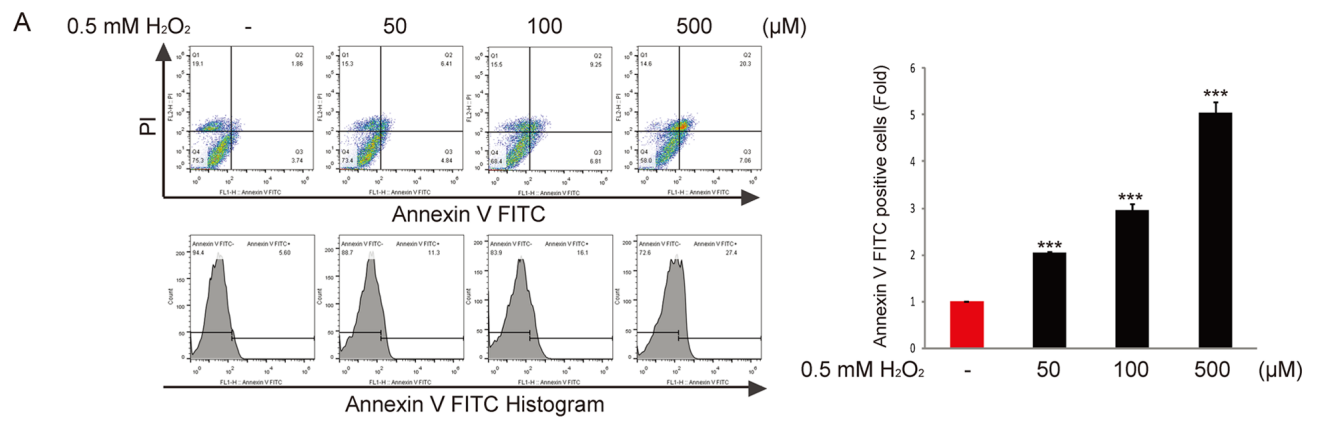

B
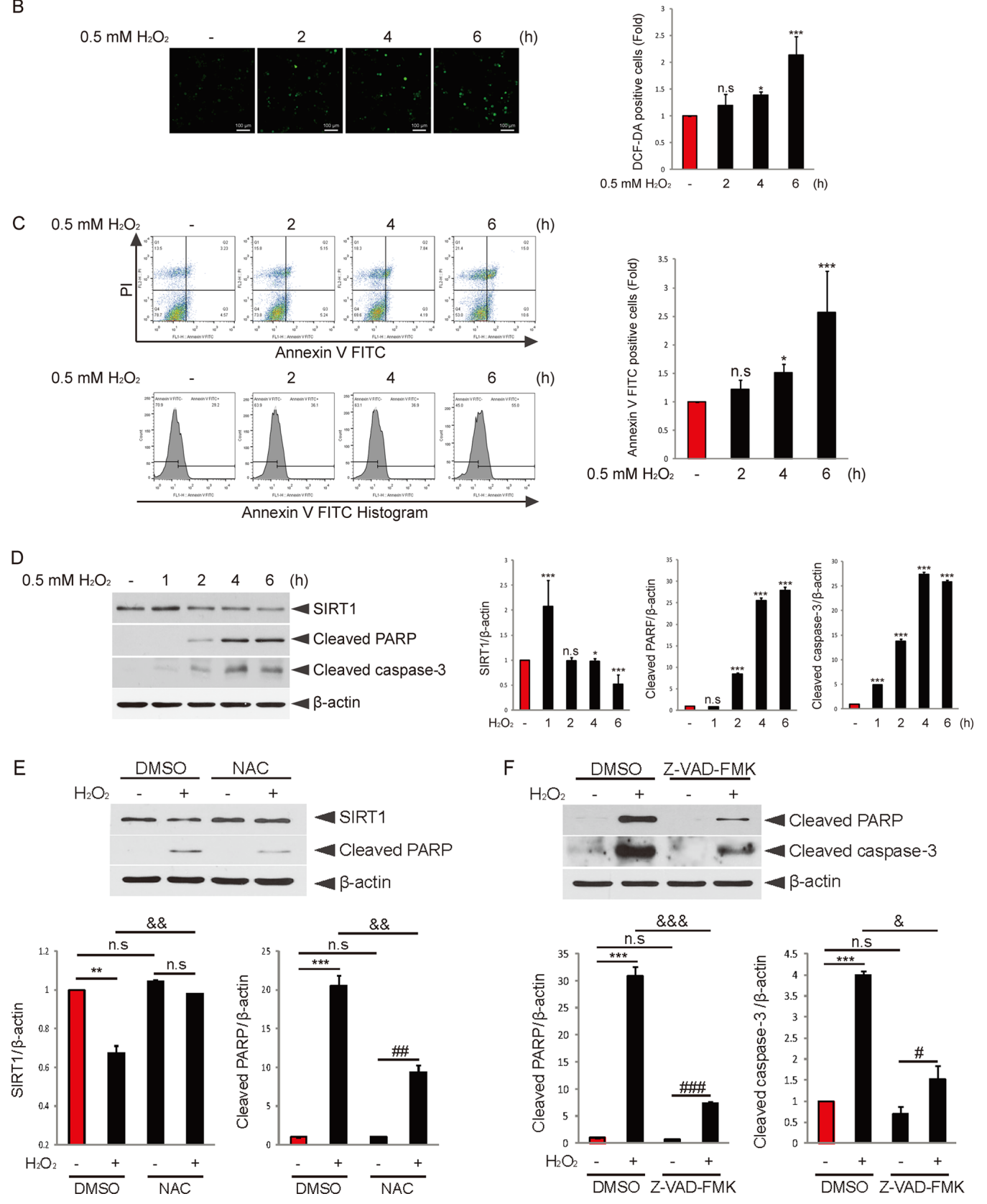

Figure 1. Granulosa cell apoptosis is induced time-dependently, and endogenous SIRT1 expression is decreased upon $\mathrm{H}_{2} \mathrm{O}_{2}$ treatment. (A) COV434 cells were incubated with or without $\mathrm{H}_{2} \mathrm{O}_{2}$ for $6 \mathrm{~h}$ at the indicated concentrations. Apoptosis analysis was performed using flow cytometry. Quantitation of Annexin V-positive cells is presented. (B) COV434 cells were incubated with or without $\mathrm{H}_{2} \mathrm{O}_{2}$ for the indicated times. DCF-DA (10 mM) was added and incubated for $20 \mathrm{~min}$. DCF fluorescence was determined using flow cytometry. Quantitation of DCF-DA-positive cells was conducted (scale bar, $100 \mu \mathrm{m}$ ). (C) COV434 cells were treated with or without $\mathrm{H}_{2} \mathrm{O}_{2}$ for the indicated times. Apoptosis analysis was performed using flow cytometry. (D) $\mathrm{COV} 434$ cells were incubated with or without $\mathrm{H}_{2} \mathrm{O}_{2}$ for the indicated times. Immunoblotting using anti-SIRT, anti-cleaved PARP, anti-cleaved caspase-3 and-actin antibodies was performed. ${ }^{*} \mathrm{P}<0.05$, ${ }^{* * *} \mathrm{P}<0.001$ vs. without $\mathrm{H}_{2} \mathrm{O}_{2}$ group. (E) COV434 cells were pretreated with DMSO or NAC $(5 \mathrm{mM})$ for $2 \mathrm{~h}$ and then incubated with or without $\mathrm{H}_{2} \mathrm{O}_{2}$ for $6 \mathrm{~h}$. Immunoblotting using SIRT1 or cleaved PARP antibody was performed. (F) COV434 cells were pretreated with DMSO or Z-VAD-FMK for $2 \mathrm{~h}$ and then incubated with or without $\mathrm{H}_{2} \mathrm{O}_{2}$ for $6 \mathrm{~h}$. Immunoblotting using cleaved PARP or caspase- 3 antibody was conducted. Representative images of three independent experiments are shown. ${ }^{* *} \mathrm{P}<0.01,{ }^{* * * *} \mathrm{P}<0.001 ;{ }^{\#} \mathrm{P}<0.05,{ }^{\# \prime} \mathrm{P}<0.01,{ }^{\# \# \#} \mathrm{P}<0.001 ;{ }^{\circledR} \mathrm{P}<0.05,{ }^{\&} \mathrm{P}<0.01,{ }^{\text {\&\&\& }} \mathrm{P}<0.001$ (two-way ANOVA with Bonferroni's correction). n.s. non-significant; NAC, N-acetyl-L-cysteine; SIRT1, sirtuin 1; PARP, poly(ADP-ribose) polymerase; H2DCFDA, 2',7'-Dichlorofluorescein diacetate. 
The effective antioxidant NAC was used to block $\mathrm{H}_{2} \mathrm{O}_{2}$ action. To investigate the effect of NAC on cleaved PARP or SIRT1 expression levels regulated by $\mathrm{H}_{2} \mathrm{O}_{2}$, COV434 cells were pretreated with NAC for $2 \mathrm{~h}$ and then incubated with or without $\mathrm{H}_{2} \mathrm{O}_{2}$ for $6 \mathrm{~h}$. Cotreatment with NAC effectively restored $\mathrm{H}_{2} \mathrm{O}_{2}$-downregulated SIRT1 expression and attenuated $\mathrm{H}_{2} \mathrm{O}_{2}$-upregulated PARP expression compared with the $\mathrm{H}_{2} \mathrm{O}_{2}$ only group (Fig. 1E). Moreover, it was evaluated whether $\mathrm{H}_{2} \mathrm{O}_{2}$-induced cell death was implicated in the caspase-dependent apoptotic pathway. Cotreatment with Z-VAD-FMK, a well-known pan caspase inhibitor, significantly decreased the expression levels of cleaved PARP and caspase-3 upregulated by $\mathrm{H}_{2} \mathrm{O}_{2}$ compared with the $\mathrm{H}_{2} \mathrm{O}_{2}$ only group (Fig. $1 \mathrm{~F}$ ). These findings suggested that $\mathrm{H}_{2} \mathrm{O}_{2}$-induced ROS production resulted in granulosa cell apoptosis in a caspase-dependent manner, and that SIRT1 may serve a key role in oxidative stress-induced granulosa cell apoptosis.

Inhibition of SIRT1 expression or activity promotes $\mathrm{H}_{2} \mathrm{O}_{2}$-induced granulosa cell apoptosis and p53 acetylation. It has been reported that SIRT1 deacetylates p53, thereby suppressing stimuli-induced apoptosis $(27,28)$. Based on these studies, it was examined whether regulation of SIRT1 activity or expression affects $\mathrm{p} 53$ activity to contribute to $\mathrm{H}_{2} \mathrm{O}_{2}$-induced granulosa cell apoptosis. COV434 cells were cotreated with or without $\mathrm{H}_{2} \mathrm{O}_{2}$ plus the SIRT1 inhibitor EX527. $\mathrm{H}_{2} \mathrm{O}_{2}$ treatment decreased SIRT1 expression, and increased cleaved PARP and acetylated p53 expression levels (Fig. 2A). In addition, cotreatment with EX527 resulted in a higher increase in PARP and acetylated p53 expression levels, but only affected SIRT1 expression slightly. Knockdown of SIRT1 expression via lentivirus-mediated SIRT1 shRNA abolished SIRT1 expression and enhanced the expression levels of cleaved PARP and acetylated p53 induced by $\mathrm{H}_{2} \mathrm{O}_{2}$ treatment compared with the control shRNA group (Fig. 2B).

Next, the effect of a SIRT1 inhibitor or activator on $\mathrm{H}_{2} \mathrm{O}_{2}$-induced granulosa cell apoptosis was investigated. The results demonstrated that cotreatment with the SIRT1 activator SRT1720 diminished $\mathrm{H}_{2} \mathrm{O}_{2}$-induced granulosa cell apoptosis (Fig. 2C). By contrast, cotreatment with EX527 enhanced apoptosis. These results indicated that the expression level or activity of SIRT1 may be a key factor that determines $\mathrm{H}_{2} \mathrm{O}_{2}$-induced granulosa cell apoptosis. Moreover, it was suggested that p53 activity regulated by SIRT1 activity or expression may contribute to apoptosis.

Knockdown of p53 decreases PUMA and PMAIP1 expression levels and granulosa cell apoptosis induced by $\mathrm{H}_{2} \mathrm{O}_{2}$. To examine whether p53 serves a key role in $\mathrm{H}_{2} \mathrm{O}_{2}$-induced granulosa cell apoptosis, each control siRNA or p53 siRNA was expressed in COV434 cells. The results indicated that knockdown of p53 attenuated granulosa cell apoptosis induced by $\mathrm{H}_{2} \mathrm{O}_{2}$ treatment (Fig. 3A). Next, to investigate the mRNA expression levels of p53 and its target genes BAX, BIM, PUMA and PMAIP1, COV434 cells were transfected with control siRNA or p53 siRNA. Following $48 \mathrm{~h}$ of transfection, cells were incubated with or without $\mathrm{H}_{2} \mathrm{O}_{2}$ for $6 \mathrm{~h}$. RT-qPCR analysis demonstrated that the mRNA expression levels of PUMA, PMAIP1 and BAX induced by $\mathrm{H}_{2} \mathrm{O}_{2}$ were significantly decreased by knockdown of p53 compared with the control siRNA $+\mathrm{H}_{2} \mathrm{O}_{2}$ group. Furthermore, p53 expression was slightly decreased by p53 knockdown compared with the control siRNA $+\mathrm{H}_{2} \mathrm{O}_{2}$ group. Whereas, $\mathrm{BIM}$ expression was slightly increased by p53 knockdown compared with the control siRNA $+\mathrm{H}_{2} \mathrm{O}_{2}$ group (Fig. 3B). To confirm these findings, immunoblotting analysis was performed. The results indicated that knockdown of p53 significantly decreased the expression levels of p53, PUMA, PMAIP1 and cleaved PARP, and reduced SIRT1 expression slightly, compared with the control siRNA group (Fig. 3C). Thus, it was suggested that p53 may be a critical effector of $\mathrm{H}_{2} \mathrm{O}_{2}$-induced granulosa cell apoptosis, and that PUMA and PMAIP1 may be implicated in the regulation of apoptosis.

Knockdown of PUMA or PMAIPI attenuates $\mathrm{H}_{2} \mathrm{O}_{2}$-induced granulosa cell apoptosis. As indicated by the results, PUMA and PMAIP1 are potential targets for p53-mediated granulosa cell apoptosis upon $\mathrm{H}_{2} \mathrm{O}_{2}$ treatment. To examine whether knockdown of PUMA or PMAIP1 affects $\mathrm{H}_{2} \mathrm{O}_{2}$-induced granulosa cell apoptosis, $\mathrm{COV} 434$ cells were transfected with PUMA or PMAIP1 siRNA for $48 \mathrm{~h}$ and then treated with $\mathrm{H}_{2} \mathrm{O}_{2}$ for $6 \mathrm{~h}$. Knockdown of PUMA decreased both cleaved PARP expression (Fig. 4A) and the apoptosis (Fig. 4B) induced by $\mathrm{H}_{2} \mathrm{O}_{2}$ compared with each control siRNA group. Additionally, the transfection of PMAIP1 siRNA significantly decreased $\mathrm{H}_{2} \mathrm{O}_{2}$-induced cleavage PARP expression (Fig. 4C) and apoptosis (Fig. 4D). Collectively, the results suggested that PUMA and PMAIP1 mediated $\mathrm{H}_{2} \mathrm{O}_{2}$-induced granulosa cell apoptosis via the SIRT1/p53 axis.

\section{Discussion}

A previous study suggested that the apoptotic rate of granulosa cells tended to be higher in patient who are infertile compared with a control group (29). Additionally, the incidence of granulosa cell apoptosis was higher in patients with $<6$ oocytes compared with patients with $\geq 6$ oocytes, and was also increased in patients who are not pregnant compared with patients who are pregnant (30). Therefore, the regulation of granulosa cell apoptosis appears to be critical, and accumulating evidence indicates that factors associated with granulosa cell apoptosis can act as targets for clinical applications $(2,31)$. It has also been reported that granulosa cell apoptosis is increased in a SIRT1 knockdown group $(18,32)$. Additionally, SIRT1 has been proposed to protect oocytes, and the activity of SIRT1 can preserve oocyte capacity in oxidative stress-mediated ovarian dysfunction, including aging (33). Consistent with these studies, the present results indicated that SIRT1 knockdown accelerated oxidative stress-induced COV434 granulosa cell apoptosis. The human COV434 granulosa cell line was used in the current study. It has been suggested that COV434 cells have three distinct properties that are essential in granulosa cells, including: Production of $17 \beta$-estradiol in response to follicle stimulating hormone, the presence of specific molecular markers of apoptosis, such as bcl-2/adenovirus E1B $19 \mathrm{kDa}$ interacting protein (Nip)1, Nip2, bcl-2 homologous antagonist/killer and Bax, enabling the induction of follicular atresia and the capacity to form intercellular connections with cells surrounding an oocyte (34). 
A

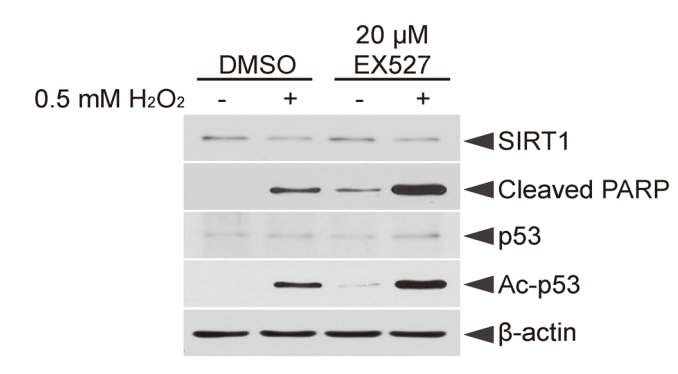

B

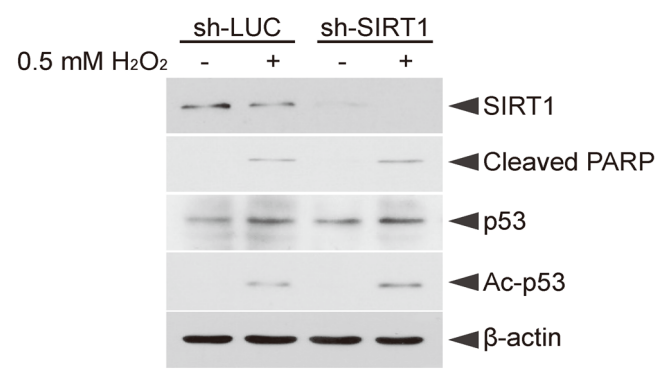

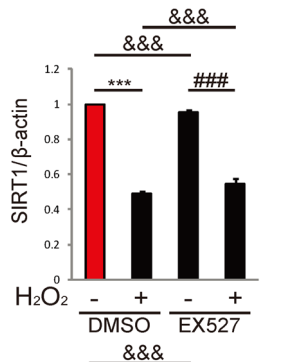
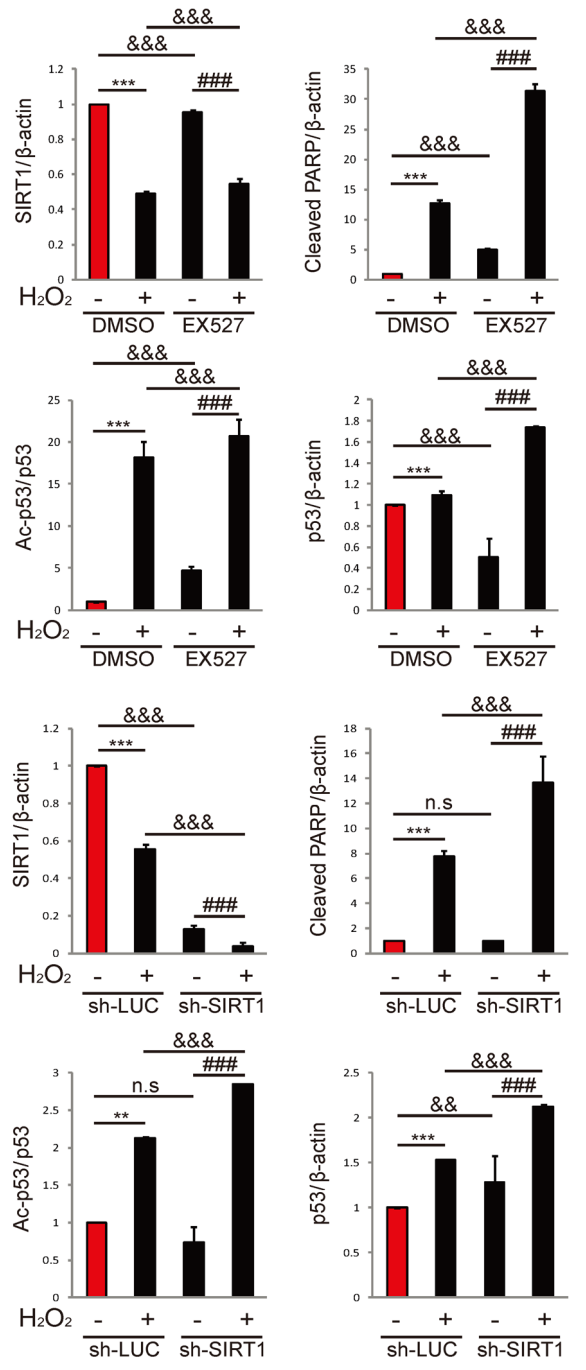
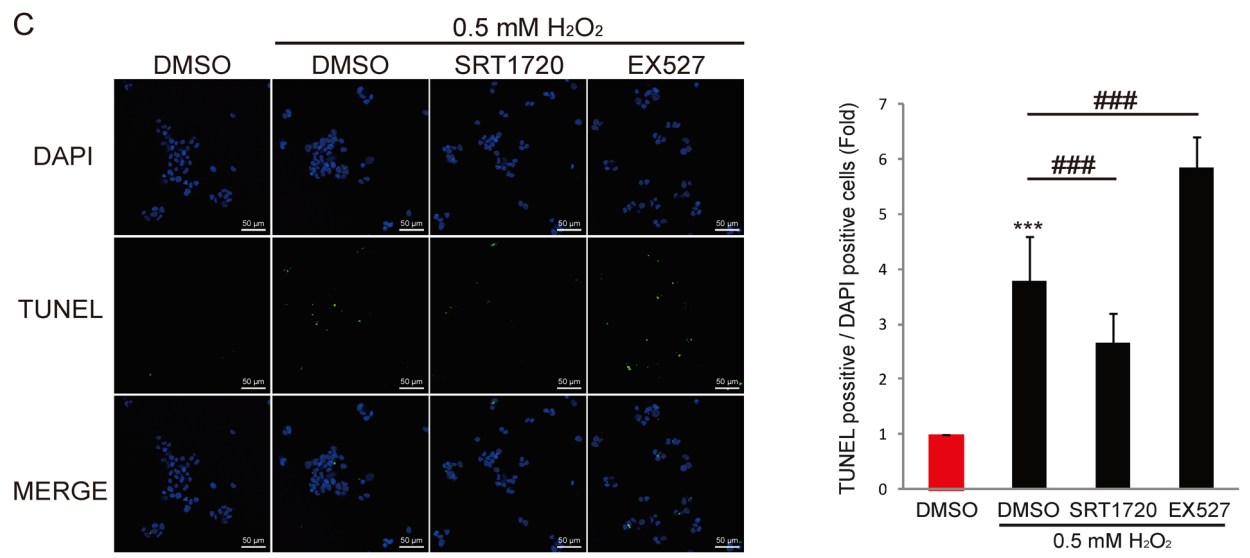

Figure 2. Regulation of SIRT1 activity affects $\mathrm{H}_{2} \mathrm{O}_{2}$-induced p53 acetylation and granulosa cell apoptosis. (A) COV434 cells were pretreated with DMSO or EX527 for $2 \mathrm{~h}$ and then incubated with or without $\mathrm{H}_{2} \mathrm{O}_{2}$ for $6 \mathrm{~h}$. Immunoblotting using anti-SIRT1, anti-cleaved PARP, anti-p53, anti-Ac-p53 and $\beta$-actin antibodies was performed. ${ }^{* * *} \mathrm{P}<0.001$ vs. DMSO; ${ }^{\# \# *} \mathrm{P}<0.001$ vs. EX527; ${ }^{\& \& \&} \mathrm{P}<0.001$ (two-way ANOVA with Bonferroni's correction). (B) COV434 cells were transduced with sh-LUC or sh-SIRT1 for $48 \mathrm{~h}$ and then treated with or without $\mathrm{H}_{2} \mathrm{O}_{2}$ for $6 \mathrm{~h}$. Immunoblotting was performed using the indicated antibody. ${ }^{* *} \mathrm{P}<0.01,{ }^{* * *} \mathrm{P}<0.001 ;{ }^{\# \# \#} \mathrm{P}<0.001$; ${ }^{\& \& \&} \mathrm{P}<0.001$ (two-way ANOVA with Bonferroni's correction). (C) COV434 cells were pretreated with DMSO, EX527 or SRT1720 for $2 \mathrm{~h}$ and then incubated with or without $\mathrm{H}_{2} \mathrm{O}_{2}$ for $6 \mathrm{~h}$. Cells were fixed and then analyzed for apoptosis via TUNEL assay. Nuclei were stained with DAPI. The ratio of TUNEL-positive cells to DAPI-positive cells is presented. Representative images of three independent experiments are provided (scale bar, $50 \mu \mathrm{m}){ }^{* * *} \mathrm{P}<0.001$ vs. DMSO; ${ }^{* \# \#} \mathrm{P}<0.001$. N.S., non-significant; sh-LUC, lentivirus-mediated LUC shRNA; sh-SIRT1, SIRT1 shRNA; SIRT1, sirtuin 1; PARP, poly(ADP-ribose) polymerase; Ac, acetylated.

It has been reported that p53 mediates granulosa cell apoptosis and that p53 induction in granulosa cells is harmful to ovarian function by disrupting oocyte quality $(10,35)$. In addition, PUMA and PMAIP1 are downstream targets of $\mathrm{p} 53$ and $\mathrm{BH} 3$-only proteins that inhibit the pro-survival Bcl2 family (36). PUMA knockout mice retain 
A
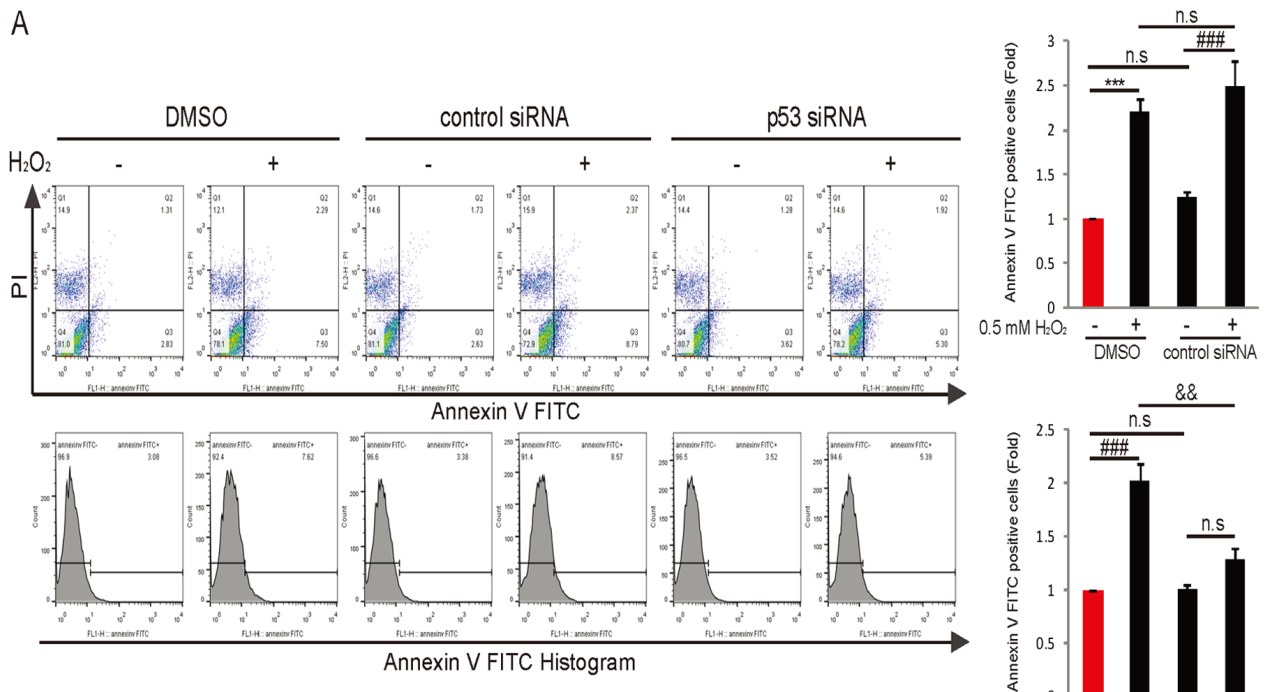

B
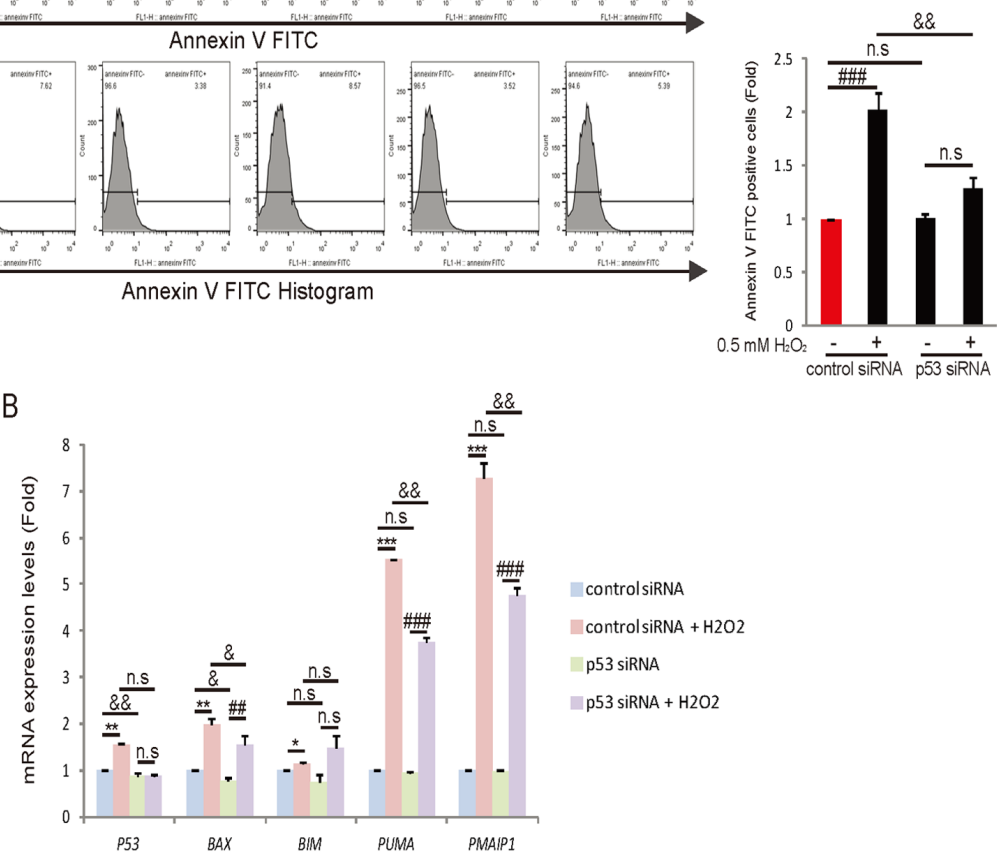

control siRNA

control siRNA + $\mathrm{H}_{2} \mathrm{O} 2$

p53 siRnA

p53 siRNA + H2O2

C
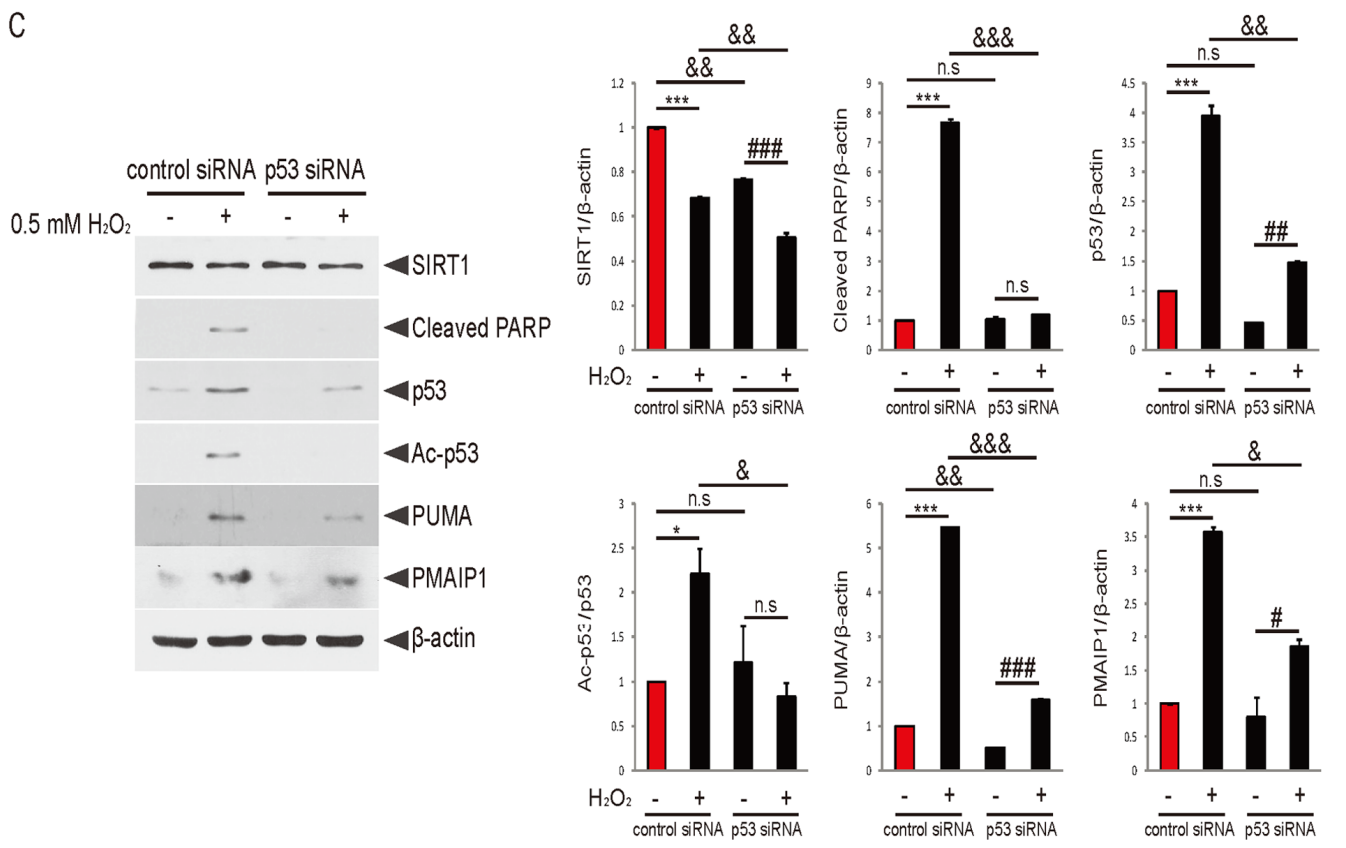

Figure 3. Knockdown of p53 attenuates $\mathrm{H}_{2} \mathrm{O}_{2}$-induced PUMA and PMAIP1 expression levels and granulosa cell apoptosis. (A) COV434 cells were treated with DMSO or transfected with control siRNA or p53 siRNA. Following $48 \mathrm{~h}$ of transfection, cells were incubated with or without $\mathrm{H}_{2} \mathrm{O}_{2}$ for $6 \mathrm{~h}$ and then analyzed for apoptosis using flow cytometry. Quantification of Annexin V-positive cells is presented. ${ }^{* * *} \mathrm{P}<0.001 ;{ }^{\# \# \#} \mathrm{P}<0.001 ;$ \& \& $\mathrm{P}<0.01$ (two-way ANOVA with Bonferroni's correction). (B) COV434 cells were transfected with control siRNA or p53 siRNA for $48 \mathrm{~h}$, and then cells were treated with or without $\mathrm{H}_{2} \mathrm{O}_{2}$ for $6 \mathrm{~h}$. Reverse transcription-quantitative PCR analysis was performed using the indicated primers. The relative mRNA expression normalized to GAPDH expression is displayed. ${ }^{*} \mathrm{P}<0.05,{ }^{* *} \mathrm{P}<0.01,{ }^{* * *} \mathrm{P}<0.001 ;{ }^{\# \#} \mathrm{P}<0.01,{ }^{\# \# "} \mathrm{P}<0.001 ;{ }^{\&} \mathrm{P}<0.05$, \&\& $\mathrm{P}<0.01$ (two-way ANOVA with Bonferroni's correction). (C) COV434 cells were transfected with control siRNA or p53 siRNA. Following $48 \mathrm{~h}$ of transfection, cells were treated with or without $\mathrm{H}_{2} \mathrm{O}_{2}$ for $6 \mathrm{~h}$. Protein expression levels of SIRT1, cleaved PARP, p53, Ac-p53, PUMA and PMAIP1 were estimated using immunoblotting. Representative results of three independent experiments are shown. " $\mathrm{P}<0.05,{ }^{* * *} \mathrm{P}<0.001 ;{ }^{\#} \mathrm{P}<0.05,{ }^{\# \#} \mathrm{P}<0.01,{ }^{\# \# \#} \mathrm{P}<0.001 ;{ }^{~} \mathrm{P}<0.05,{ }^{\& \&} \mathrm{P}<0.01$, \&\&\& $\mathrm{P}<0.001$ (two-way ANOVA with Bonferroni's correction). N.S., non-significant; Ac, acetylated; SIRT1 shRNA; SIRT1, sirtuin 1; PARP, poly(ADP-ribose) polymerase; siRNA, small interfering RNA; BIM, Bcl2 like 11; PUMA, p53-upregulated modulator of apoptosis; PMAIP1, phorbol-12-myristate-13-acetate-induced protein 1. 
A

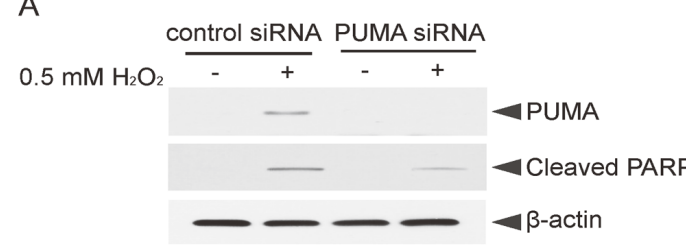

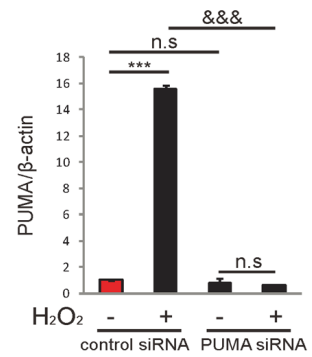

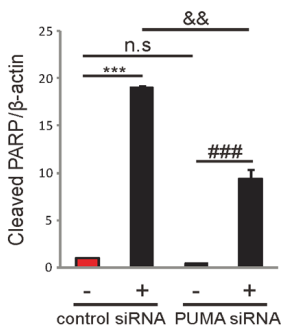

B
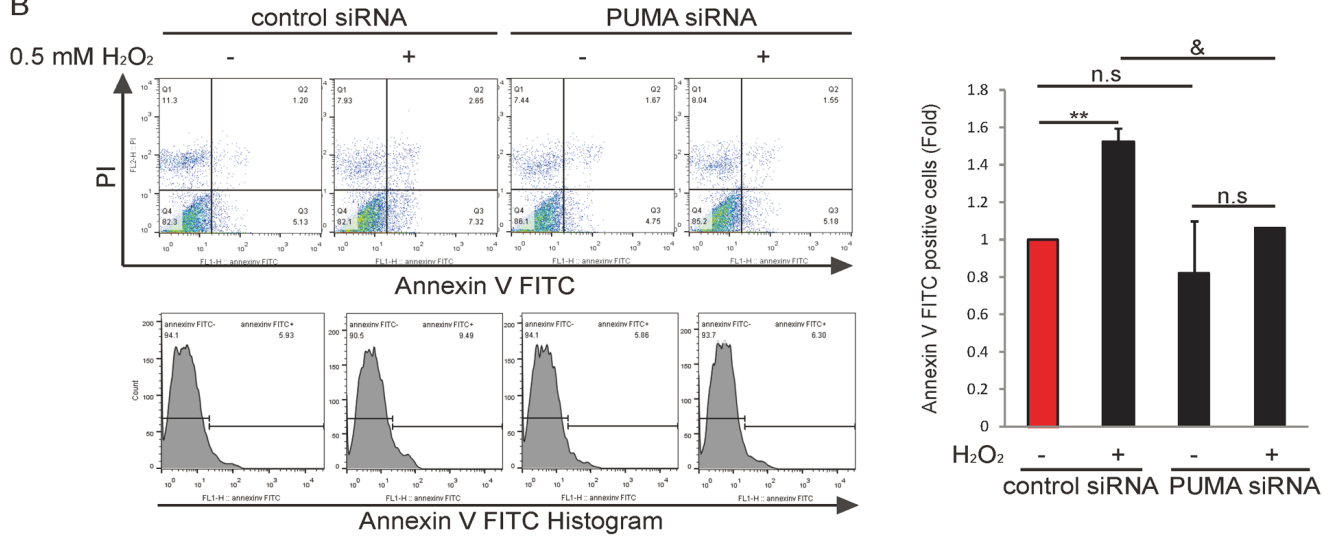

C
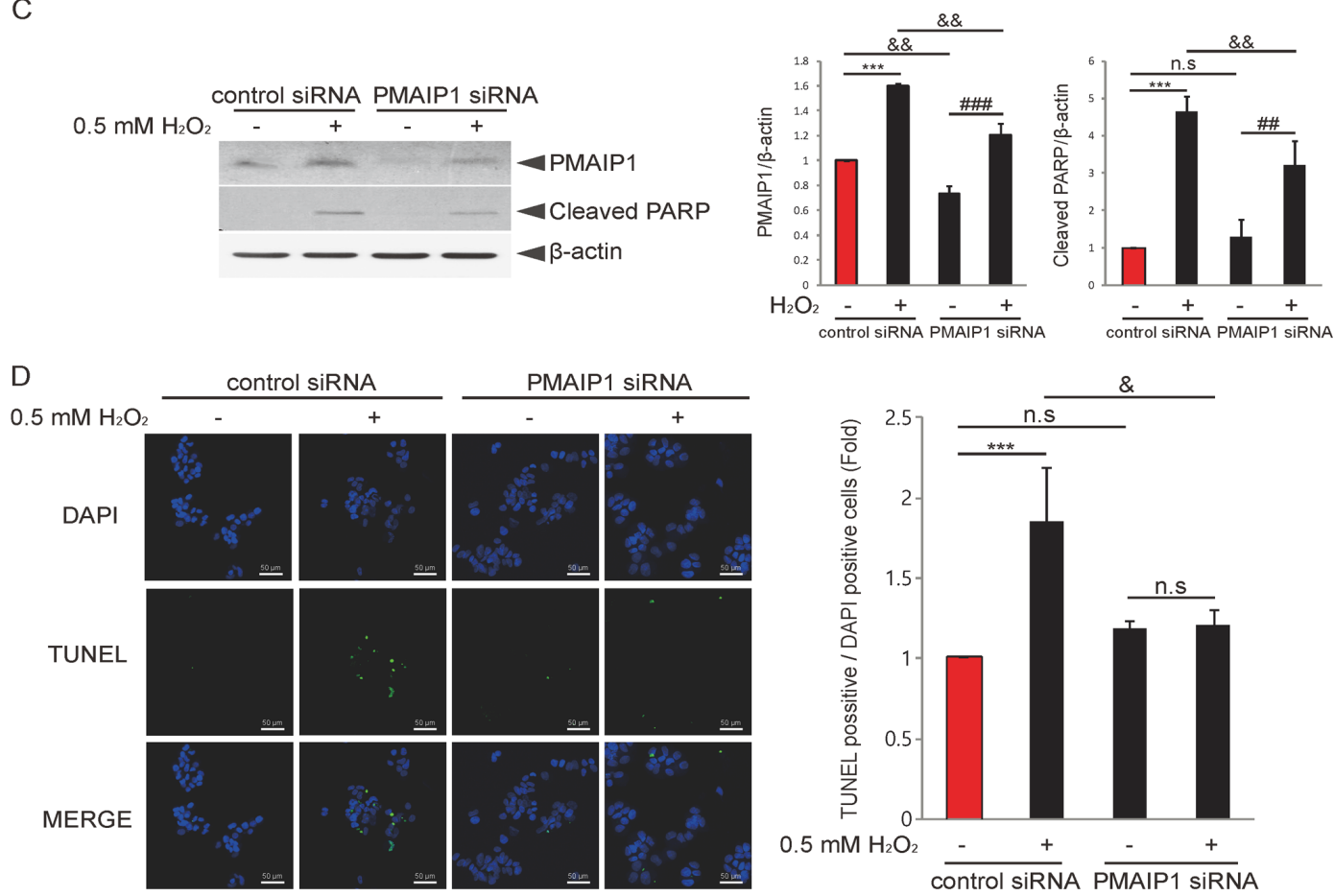

Figure 4. Knockdown of PUMA or PMAIP1 decreases $\mathrm{H}_{2} \mathrm{O}_{2}$-induced granulosa cell apoptosis. (A) COV434 cells were transfected with control siRNA or PUMA siRNA for $48 \mathrm{~h}$ and then treated with or without $\mathrm{H}_{2} \mathrm{O}_{2}$ for $6 \mathrm{~h}$. Immunoblotting using PUMA or cleaved PARP antibodies was performed. ${ }^{* * *} \mathrm{P}<0.001$;

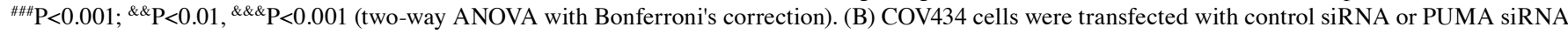
for $48 \mathrm{~h}$ and then incubated with or without $\mathrm{H}_{2} \mathrm{O}_{2}$ for $6 \mathrm{~h}$. Cells were subjected to flow cytometry for apoptosis analysis. Quantitation of Annexin V-positive cells is presented. ${ }^{* *} \mathrm{P}<0.01 ;{ }^{\circledR} \mathrm{P}<0.05$ (two-way ANOVA with Bonferroni's correction). (C) COV434 cells were transfected with control siRNA or PMAIP1 siRNA for $48 \mathrm{~h}$ and then treated with or without $\mathrm{H}_{2} \mathrm{O}_{2}$ for $6 \mathrm{~h}$. Immunoblotting using PMAIP1 or cleaved PARP antibodies was performed. ${ }^{* * *} \mathrm{P}<0.001$; ${ }^{\# \prime} \mathrm{P}<0.01$, ${ }^{\# \# \# 4} \mathrm{P}<0.001$; \&\& $\mathrm{P}<0.01$ (two-way ANOVA with Bonferroni's correction). (D) COV434 cells were transfected with control siRNA or PMAIP1 siRNA for $48 \mathrm{~h}$ and then incubated with or without $\mathrm{H}_{2} \mathrm{O}_{2}$ for $6 \mathrm{~h}$. Cells were subjected to TUNEL assay for apoptosis analysis. Nuclei staining was performed with DAPI. The ratio of TUNEL-positive cells to DAPI-positive cells is indicated, as well as representative results of three independent experiments (scale bar, $50 \mu \mathrm{m}){ }^{* * * *} \mathrm{P}<0.001$; ${ }^{\&}$ P $<0.05$ (two-way ANOVA with Bonferroni's correction). N.S., non-significant; PARP, poly(ADP-ribose) polymerase; siRNA, small interfering RNA; BIM, BCL2 like 11; PUMA, p53-upregulated modulator of apoptosis; PMAIP1, phorbol-12-myristate-13-acetate-induced protein 1.

primordial follicles and preserve their reproductive function in DNA-damaging conditions compared with wild-type mice, and primordial follicular oocytes from PUMA or PUMA/PMAIP1 double-knockout mice are protected from
DNA damage-induced apoptosis and can produce healthy offspring (37,38). Collectively, these studies demonstrate that p53 and its targets, PUMA and PMAIP1, are critical effectors regulating granulosa cell apoptosis. 
ROS-mediated oxidative stress can induce apoptosis and is associated with several diseases, including cancer, diabetes and liver fibrosis (39). It has been suggested that under oxidative stress conditions, SIRT1 regulates the activity of the transcription factor p53, a tumor suppressor and inducer of apoptosis, and the FOXO family to affect cell survival or apoptosis (19). Based on these reports, the present study aimed to elucidate the mechanism linking SIRT1 with p53 in oxidative stress-induced granulosa cell apoptosis. The current results indicated that p53 acetylation upregulated by SIRT1 suppression upon $\mathrm{H}_{2} \mathrm{O}_{2}$ treatment promoted granulosa cell apoptosis. Moreover, it has been reported that cytoplasmic p53 deacetylation by ROS-activated SIRT1 in mouse embryonic stem cells suppresses p53 nuclear translocation, leading to p53 translocation into mitochondria, its binding to $\mathrm{Bcl} 2$ and cytochrome $c$ release, suggesting a role for SIRT1 in p53 transcription-independent apoptosis (40). Taken together, these findings demonstrate that oxidative stress may induce cell type-specific apoptosis by activating or inactivating SIRT1 in a p53 transcription-dependent or p53 transcription-independent manner, indicating the significance of SIRT1 activity against p53.

In conclusion, the present study demonstrated that SIRT1 downregulation by $\mathrm{H}_{2} \mathrm{O}_{2}$ treatment promoted p53 activity, thereby accelerating granulosa cell apoptosis. The findings of this study improve the understanding of the mechanistic role of the SIRT1/p53 axis in the regulation of oxidative stress-induced granulosa cell apoptosis, and suggest the potential use of SIRT1 activators as a strategy to inhibit granulosa cell apoptosis. However, the present study did not identify the detailed underlying molecular mechanism via which the SIRT1/p53 regulatory axis regulates granulosa cell apoptosis. Thus, future studies will aim to investigate novel target proteins regulated by SIRT1 in the $\mathrm{H}_{2} \mathrm{O}_{2}$ response, as well as examine the effect of p53 post-translational modification on oxidative stress-induced granulosa cell apoptosis.

\section{Acknowledgements}

Not applicable.

\section{Funding}

This work was supported by National Research Foundation of Korea (NRF) grants funded by the Korean government (grant no. NRF-2019R1I1A3A01063191). This work was also supported by the Priority Research Centers Program through the NRF (grant no. NRF-2017R1A6A1A03015713).

\section{Availability of data and materials}

All data generated or analyzed during the present study are included in this published article.

\section{Authors' contributions}

SAP and NRJ conducted the experiments, collected the data and analyzed the data. JHP analyzed the data. SMO designed and supervised the project. SAP, NRJ and SMO wrote the manuscript. All authors read and approved the final manuscript.

\section{Ethics approval and consent to participate}

Not applicable.

\section{Patient consent for publication}

Not applicable.

\section{Competing interests}

The authors declare that they have no competing interests.

\section{References}

1. Matsuda F, Inoue N, Manabe N and Ohkura S: Follicular growth and atresia in mammalian ovaries: Regulation by survival and death of granulosa cells. J Reprod Dev 58: 44-50, 2012.

2. Zhao Z, Shi H, Li J, Zhang Y, Chen C and Guo Y: Cumulative live birth rates according to the number of oocytes retrieved following the 'freeze-all' strategy. Reprod Biol Endocrinol 18: 14, 2020.

3. Vabre P, Gatimel N, Moreau J, Gayrard V, Picard-Hagen N, Parinaud $J$ and Leandri RD: Environmental pollutants, a possible etiology for premature ovarian insufficiency: A narrative review of animal and human data. Environ Health 16: 37, 2017.

4. Boone DL, Carnegie JA, Rippstein PU and Tsang BK: Induction of apoptosis in equine chorionic gonadotropin (eCG)-primed rat ovaries by anti-eCG antibody. Biol Reprod 57: 420-427, 1997.

5. Boone DL and Tsang BK: Caspase-3 in the rat ovary: Localization and possible role in follicular atresia and luteal regression. Biol Reprod 58: 1533-1539, 1998.

6. Cecconi S, Ciccarelli C, Barberi M, Macchiarelli G and Canipari R: Granulosa cell-oocyte interactions. Eur J Obstet Gynecol Reprod Biol 115 (Suppl 1): S19-S22, 2004.

7. Clarke HJ: Regulation of germ cell development by intercellular signaling in the mammalian ovarian follicle. Wiley Interdiscip Rev Dev Biol 7: 10.1002/wdev.294, 2018.

8. Zhang JQ, Shen M, Zhu CC, Yu FX, Liu ZQ, Ally N, Sun SC, Li K and Liu HL: 3-Nitropropionic acid induces ovarian oxidative stress and impairs follicle in mouse. PLoS One 9: e86589, 2014.

9. Zhang M, Zhang Q, Hu Y, Xu L, Jiang Y, Zhang C, Ding L, Jiang R, Sun J, Sun H and Yan G: miR-181a increases FoxO1 acetylation and promotes granulosa cell apoptosis via SIRT1 downregulation. Cell Death Dis 8: e3088, 2017.

10. Haraguchi H, Hirota Y, Saito-Fujita T, Tanaka T, Shimizu-Hirota R, Harada M, Akaeda S, Hiraoka T, Matsuo M, Matsumoto L, et al: Mdm2-p53-SF1 pathway in ovarian granulosa cells directs ovulation and fertilization by conditioning oocyte quality. FASEB J 33: 2610-2620, 2019.

11. Livera G, Uzbekov R, Jarrier P, Fouchécourt S, Duquenne C, Parent AS, Marine JC and Monget P: Loss of oocytes due to conditional ablation of Murine double minute 2 (Mdm2) gene is p53-dependent and results in female sterility. FEBS Lett 590: 2566-2574, 2016

12. He M, Tan B, Vasan K, Yuan H, Cheng F, Ramos da Silva S, Lu C and Gao SJ: SIRT1 and AMPK pathways are essential for the proliferation and survival of primary effusion lymphoma cells. J Pathol 242: 309-321, 2017.

13. Kume S, Haneda M, Kanasaki K, Sugimoto T, Araki S, Isono M, Isshiki K, Uzu T, Kashiwagi A and Koya D: Silent information regulator 2 (SIRT1) attenuates oxidative stress-induced mesangial cell apoptosis via p53 deacetylation. Free Radic Biol Med 40: 2175-2182, 2006

14. Li Y, Yang G, Yang X, Wang W, Zhang J, He Y, Zhang W, Jing $T$ and Lin R: Nicotinic acid inhibits NLRP3 inflammasome activation via SIRT1 in vascular endothelial cells. Int Immunopharmacol 40: 211-218, 2016.

15. Mendelsohn AR and Larrick JW: The NAD+/PARP1/SIRT1 Axis in aging. Rejuvenation Res 20: 244-247, 2017.

16. Zha S, Li Z, Cao Q, Wang F and Liu F: PARP1 inhibitor (PJ34) improves the function of aging-induced endothelial progenitor cells by preserving intracellular $\mathrm{NAD}(+)$ levels and increasing SIRT1 activity. Stem Cell Res Ther 9: 224, 2018. 
17. Zheng T and Lu Y: SIRT1 protects human lens epithelial cells against oxidative stress by inhibiting p53-dependent apoptosis. Curr Eye Res 41: 1068-1075, 2016.

18. Han Y, Luo H, Wang H, Cai J and Zhang Y: SIRT1 induces resistance to apoptosis in human granulosa cells by activating the ERK pathway and inhibiting NF- $\mathrm{BB}$ signaling with anti-inflammatory functions. Apoptosis 22: 1260-1272, 2017.

19. Hori YS, Kuno A, Hosoda R and Horio Y: Regulation of FOXOs and p53 by SIRT1 modulators under oxidative stress. PLoS One 8: e73875, 2013.

20. Yamakuchi M and Lowenstein CJ: miR-34, SIRT1 and p53: The feedback loop. Cell Cycle 8: 712-715, 2009.

21. Vousden $\mathrm{KH}$ and Prives C: Blinded by the light: The growing complexity of p53. Cell 137: 413-431, 2009.

22. Aubrey BJ, Kelly GL, Janic A, Herold MJ and Strasser A: How does p53 induce apoptosis and how does this relate to p53-mediated tumour suppression? Cell Death Differ 25: 104-113, 2018.

23. Hosokawa K, Aharoni D, Dantes A, Shaulian E, Schere-Levy C, Atzmon R, Kotsuji F, Oren M, Vlodavsky I and Amsterdam A: Modulation of Mdm2 expression and p53-induced apoptosis in immortalized human ovarian granulosa cells. Endocrinology 139: 4688-4700, 1998.

24. Yang H, Xie Y, Yang D and Ren D: Oxidative stress-induced apoptosis in granulosa cells involves JNK, p53 and Puma. Oncotarget 8: 25310-25322, 2017.

25. Livak KJ and Schmittgen TD: Analysis of relative gene expression data using real time quantitative PCR and the 2(-Delta Delta C(T)) method. Methods 25: 402-408, 2001.

26. Tatone C, Di Emidio G, Vitti M, Di Carlo M, Santini S Jr, D'Alessandro AM, Falone S and Amicarelli F: Sirtuin functions in female fertility: Possible role in oxidative stress and aging. Oxid Med Cell Longev 2015: 659687, 2015.

27. Ghosh A, Sengupta A, Seerapu GPK, Nakhi A Shivaji Ramarao EVV, Bung N, Bulusu G, Pal M and Haldar D: A novel SIRT1 inhibitor, 4bb induces apoptosis in HCT116 human colon carcinoma cells partially by activating p53. Biochem Biophys Res Commun 488: 562-569, 2017.

28. Gu X, Wang Z, Gao J, Han D, Zhang L, Chen P, Luo G and Han B SIRT1 suppresses p53-dependent apoptosis by modulation of p21 in osteoblast-like MC3T3-E1 cells exposed to fluoride. Toxicol In Vitro 57: 28-38, 2019.

29. Idil M, Cepni I, Demirsoy G, Ocal P, Salihoğlu F, Senol H, Elibol F and Irez T: Does granulosa cell apoptosis have a role in the etiology of unexplained infertility? Eur J Obstet Gynecol Reprod Biol 112: 182-184, 2004.
30. Nakahara K, Saito H, Saito T, Ito M, Ohta N, Sakai N, Tezuka N, Hiroi $M$ and Watanabe $H$ : Incidence of apoptotic bodies in membrana granulosa of the patients participating in an in vitro fertilization program. Fertil Steril 67: 302-308, 1997.

31. Almeida CP, Ferreira MCF, Silveira CO, Campos JR, Borges IT, Baeta PG, Silva FHS, Reis FM and Del Puerto HL: Clinical correlation of apoptosis in human granulosa cells-A review. Cell Biol Int 42: 1276-1281, 2018

32. Xiong F, Hu L, Zhang Y, Xiao X and Xiao J: miR-22 inhibits mouse ovarian granulosa cell apoptosis by targeting SIRT1. Biol Open 5: 367-371, 2016.

33. Di Emidio G, Falone S, Vitti M, D'Alessandro AM, Vento M, Di Pietro C, Amicarelli F and Tatone C: SIRT1 signalling protects mouse oocytes against oxidative stress and is deregulated during aging. Hum Reprod 29: 2006-2017, 2014.

34. Zhang H, Vollmer M, De Geyter M, Litzistorf Y, Ladewig A, Dürrenberger M, Guggenheim R, Miny P, Holzgreve W and De Geyter C: Characterization of an immortalized human granulosa cell line (COV434). Mol Hum Reprod 6: 146-153, 2000.

35. Kim JM, Yoon YD and Tsang BK: Involvement of the Fas/Fas ligand system in p53-mediated granulosa cell apoptosis during follicular development and atresia. Endocrinology 140: 2307-2317, 1999 .

36. Chen L, Willis SN, Wei A, Smith BJ, Fletcher JI, Hinds MG, Colman PM, Day CL, Adams JM and Huang DC: Differential targeting of prosurvival $\mathrm{Bcl}-2$ proteins by their $\mathrm{BH} 3$-only ligands allows complementary apoptotic function. Mol Cell 17: 393-403, 2005.

37. Kerr JB, Hutt KJ, Michalak EM, Cook M, Vandenberg CJ, Liew SH, Bouillet P, Mills A, Scott CL, Findlay JK and Strasser A: DNA damage-induced primordial follicle oocyte apoptosis and loss of fertility require TAp63-mediated induction of Puma and Noxa. Mol Cell 48: 343-352, 2012.

38. Nguyen QN, Zerafa N, Liew SH, Morgan FH, Strasser A, Scott CL, Findlay JK, Hickey M and Hutt KJ: Loss of PUMA protects the ovarian reserve during DNA-damaging chemotherapy and preserves fertility. Cell Death Dis 9: 618, 2018.

39. Brieger K, Schiavone S, Miller FJ Jr and Krause KH: Reactive oxygen species: From health to disease. Swiss Med Wkly 142: w13659, 2012.

40. Yi J and Luo J: SIRT1 and p53, effect on cancer, senescence and beyond. Biochim Biophys Acta 1804: 1684-1689, 2010. 